\title{
ДРАГАНА ЦВЕТАНОВИЋ
}

\section{Хелсинки, Финска}

DOI 10.5937/kultura1962143C

УДК 316.72:78.067.26(497.1-089)

316.723(497.1-089)

стручни рад

\section{YUGOSPOTTNGY PEEИOHADHON XИП-XOПY}

Сажетак: Цциь овог иланка је истраживање значена и особине реп текстова кроз реконструкиију кониепта заједничког идентитета међу реперима бивие Југославије у новом над-наиионалном соиијалном контексту. Овај рад анализира видове изражавања припадности заједничком и генерачијском знаюу. Пост-југословенски регионални реп има заједничку публику која није ограничена држсавним гранищама. Главни извори овог иланка су реп текстови са соиијално-политичком поруком који су, већином, написани од стране репера рођених током 1970-их и 80-их година, због чега су повезани и са југословенским и са постјугословенским хронотопом, док је највећи део њихове публике рођен у постјугословенском амбијенту. Радна хипотеза је да репери користе културу хип-хопа и своје генераиијско знане (, југо-знаъе") као начин повезивана са својом публикам, те тако стварају нову културолочкко-идентификациону подлогу која више одговара новом, тј. новим контекстима, супростављеним званичним културолоиким политикама новонасталих држава. Ово се постиже кориићењем музичког знана и искустава југословенских генераиија кроз семпловате и интеретекстуалност, чиме се стварају важне основе за културну идентификацију будућих генераиија у Региону (ито је у супротности са званичним политикама новонасталих држава). Овај иланак се методолоики везује за кониепте језичког и културног идентитета, „југославизма", генерачије, а користи реп лирку следећих pеп уметника из Босне, Хрватске и Србије: Edo-Maаjka, Elemental, TBF, и Марчело.

Къучне речи: Југославија, регион, хип-хоп, pen, идентитет, културна политика, интертекстуалност 


\section{Југословенски и балкански (заједнички) идентитети}

Идентитети су производи разних комуникацијских и дискурзивних процеса, који се у, овом чланку посматрају кроз текстуалну, лиричну и дискурсивну анализу. Разматрајући лингвистични идентитет, Јан Бломерт (Jan Blommaert) $)^{1}$ сматра да је у питању семиотична конструкција у смислу организовања тема, ситуације, жанра, стила, ситуације, намене и сличног. Са друге стране, Стјуарт Хол (Stuart Hall) ${ }^{2}$ pacправља о културолошком идентитету, дефинишући га као пресек дискурса и праксе. Његове теорије о културолошком идентитету у касно-модерно доба нам помажу да схватимо зашто је питање идентитета постало централно питање и зашто се чак и расправља о „кризи идентитета”. Хол сматра да су модерни идентитети дислоцирани и фрагментисани, ${ }^{3}$ узимајући у обзир да су многи важни трендови постали актуални тек од скора, те да нису дефинисани до краја. Кобена Мерцер (Kobena Mercer) ${ }^{4}$ сматра да расправа о идентитетима постаје актуелна онда када је идентитет у кризи, када нешто што је требало да буде фиксно, концизно и стабилно постане ,разлоцирано” осећајем неверице и несигурности. Последњих година је концепт идентитета истраживан другим теоријским путевима, на пример концептима припадања $^{5}$ и интерсекционалности. ${ }^{6}$

Стјуарт Хол сматра да је потребно прихватити савременије схватање концепта идентитета кроз историјски објектив: пре би требало говорити о идентификацији него о идентитету, и посматрати га као стални процес: „Идентитет се ствара не толико из осећаја пуноће идентитета, који већ постоји унутар нас као личности, већ из недостатка целости која се пуни извана, али на начин на који ми замишљамо да

1 Blommaert, J. (2005) Discourse. A Critical Introduction. Cambridge: Cambridge University Press, p. 201.

2 Hall, S. and de Gay, P. (1996) Questions of Cultural Identity, Sage Publications, pp. 5-6.

3 Hall, S., Held, D. and Mc Grew, T. (eds.) (1992) Modernity and Its Futures, Cambridge: Polity Press and Open University, p. 274.

4 Mercer, K. Welcome to the jungle: identity and diversity in postmodern politics, in: Identity, Community, Culture, Difference, ed. Rutherford, J. (1990), London: Lawrence and Wishart, pp. 43-71.

5 Yuval-Davis, N. (2006) Intesectionality and Feminist Politics, European Journal of Women's Studies 13 (3), pp. 193-209.

6 Crenshaw, K. (1991) Mapping the Margins: Intersectionality, Identity Politics, and Violence against Women of Color, Stanford Law Review (43), pp. 1241-1299. 


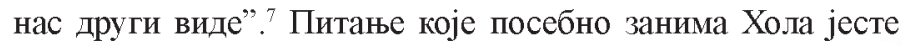
питање о улози културног идентитета у касно модерно доба и како је глобализација утицала на националне културне идентитете. Управо ово питање желимо и сами да покренемо. Националне културе конструишу идентитете тако што производе мишљења, која су прилепљена уз „нацију” и са којима људи могу да се идентификују. ${ }^{8}$ Та значења су присутна у причама, које говоре о нацијама, у сећањима која повезују садашњост нације са њеном прошлошћу, и у представама које су на основу њих створене, попут „замишљених заједница". ${ }^{9}$ Питања о националном и језичком идентитету, о регионалној припадности, провлаче се као теме овог чланка и она могу бити вићена кроз, сада већ помало застарелу идеју Имануела Волерстајна (Immanuel Wallerstein), ${ }^{10}$ да су национализми модерног света дифузни изрази жеља за асимилацијом у универзално, а истовремено за приступање особеном, односно - за поновно стварање разлика. Ова истовремена тежња ка универзалности и особености тумачи и Марија Тодорова (Марија Тодорова), ${ }^{11}$ која сматра да бившим Југословенима идентификација са Балканом значи могућност припадања хрватству, српству, македонству (итд.), тако што ће представити само једну, прочишћену страну свог идентитета.

И кад Хол дискутује о тензији између локалног и глобалног и трансформацијама припадности народностима, он се противи идеји да глобализација уништава националне идентитете ${ }^{12}$, и сматра да је већа могућност да глобализација допринесе стварању нове глобалне и нове локалне идентификације. Такође, постоји могућност да се глобализација развија истовремено са ојачавањем локалних идентитета, иако у овом сценарију Хол види зависност од логике сажимања времена и простора. Овај сценарио, по њему, садржи аспекте доминације запада у глобалном контексту, иако су

7 Hall, S., Held, D. and Mc Grew, T. (eds.) (1992) Modernity and Its Futures, Cambridge: Polity Press and Open University, p. 287.

8 Исто, стр. 293.

9 Anderson, B. (1983) Imagined Communities: Reflections on the Origins and Spread of Nationalism, London: Verso.

10 Wallerstein, I. (1984) The Politics of the World-Economy: The States, the Movement and the Civilization, Cambridge: University of Cambridge Press Syndicate, pp. 166-167.

11 Todorova, M. (1997) Imagining the Balkans, Oxford: Oxford University Press, p. 53.

12 Hall, S., Held, D. and Mc Grew, T. (eds.) (1992) Modernity and Its Futures, Cambridge: Polity Press and Open University, p. 304. 
културни идентитети релативизовани глобално управо због сажимања времена и простора. ${ }^{13}$

Ако посматрамо хип-хоп културу и њен утицај на локалне културе као врсту глобализационог процеса, који утиче на локалне културолошке и језичке идентификације на Балкану, можемо се упитати да ли је упште могуће остварити осећај кохерентних и независних идентитета у глобално време. Иако је могуће да глобализација води ка јачању локалних идентитета или продукщија, ${ }^{14}$ она има плуралистички утицај на идентитете: отвара палету могућности нових позиција, чинећи идентитете више позиционираним, политичким, плуралистичким и различитим, а мање фиксним и јединственим, мање трансисторијским. Код неких идентитета и даље се рефлектују „традиционалистичка” гледања, док су други субјекти међуигре историје, политике, репрезентације, различитости, и немогућности бивања јединственим или чистим. Ово гледиште је врло блиско идејама Хомија Бабе (Homi Bhabha) и његовом концепту о преговорима или културним преводима (енгл. negotiation or cultural translation), за које он тврди да је субверзиван у самом себи, и да нуди једини могући начин да трансформише свет и да помогне стварању нечег сасвим новог. У том смислу, он сматра да је еманципаторски продужетак политике могућ једино у пољу културне продукције, која прати логику културних превода (cultural translation). ${ }^{15}$

Хол подсећа да су и либерализам и марксизам, свако на свој начин, сугерисали да ће повезаност локалног и посебног морати својевремено да узмакне зарад више универзалних и космополитских вредности. ${ }^{16}$ По овом схватању нација и етницитет су архаични облици припадања, такви феномени који би временом били истопљени револуционирном силом модернизације. На основу ових „метанаратива” модернизације, ирационална приврженост локалном и особеном, традицији и коренима, националним митовима и „замишљеним заједницама", временом би била замењена рационалнијим и универзалнијим идентитетима. На крају, глобализација изгледа да не тријумфује ни произвођењем „глобалног”, нити упорно, националистички нагалашеног,,локалног”.

У наставку, размотрићу дискурсе идентитета у реп лирици. Југоспотинг (Yugospotting) је појам који означава

13 Исто, стр. 306.

14 Исто, стр. 308.

15 Bhabha, H. (1994) The Location of Culture, London: Routledge.

16 Hall, S., Held, D. and Mc Grew, T. (eds.) (1992) Modernity and Its Futures, Cambridge: Polity Press and Open University, p. 314. 
југосемантику реп музике, која се огледа у музици (семплови), знању, сећањима, личним искуствима и језику. Самобалканизација је процес који је неодвојив од југоспотинга, а може се тумачити као изналажење таквог заједничког идентитета који би био у мањој мери повезан са негативним искуствима бивше југословенске заједнице.

\section{Транснауионалност $и$ заједнички идентитети репа}

У оквиру студија хип-хопа, дисциплини која је у сталном развоју од 90-их, често се среће концепт домаћег или одомаћеног репа, када се говори о аутентичности локалних видова ове културе. ${ }^{17}$ Иако је концепт домаћег или одомаћености недовољно истражен, он овде ипак може бити од помоћи. У реп музици на Западном Балкану, један од облика аутентичности јесу и транснационализам и регионализам, који су се формирали од 1990-их и на које су репери и њихова публика морали да се навикну. Друга важна карактеристика локалног репа огледа се у коришћењу (бившег) заједничког језика, односно националних језика, који омогућавају да се „националне” сцене прате кроз новонастале националне границе. Начин на који хип-хоп култура постаје локални израз у контрадикцији је са чињеницом да реп публика прати и регионални реп, који јесте локалан сам по себи, али и који садржи неколико суб-локалних облика. У том смислу, локалност репа на овим просторима подразумева и један облик транснационализма. Генерације репера рођене у СФРЈ нису одмах у својим текстовима изразиле потребу да нађу сличну тематику, или да се повежу са „новим” културним локалним сферама, већ се то десило тек почетком 2000-их. ${ }^{18}$ Тек је неколико извођача преузело улогу отвореног заговорника одомаћене локалне регионалне хип-хоп сцене, што се сматрало добродошлим доприносом реп култури и култури уопште. Али то је у исти мах био чин који је исувише интелектуалан (и у том смислу неаутентичан), посебно за културу коју одликује верност „улици” и заинтересованост за маргинализоване, личне наративе. На другој страни, они репери, који у својим текстовима нису говорили о некаквом заједничком ексјугословенском реп простору, такође су сарађивали са регионалним реперима и нашли регионалну

17 Wermuth, M. Rap in Low Countries, in: Global Noise: Rap and Hip-hop outside the USA, ed. Mitchell, T. (2001), Middletown, CT: Wesleyan University Press.

18 Cvetanović, D. (2014) Petturien tai patriootien räppi (Traitor or Patriot rap?), Idäntutkimus vol. 1, pp. 3-15; Cvetanović, D. (2015) Balkanin nuoret konfliktin jälkeen (Youth in the after-war Balkan), Idäntutkimus vol, pp. 4, 28-44. 
публику. Дискусија о транснационалности и регионалности ексјугословенског репа везује се и за скорију дискусију о супер-диверзитету; у којој се истакао захтев да се транснационализам и идентитет упореде. ${ }^{19}$ Транснационалне везе размене и учествовања базирани су на одређеној перцепцији о заједничком идентитету, обично на основу места рођења и културолошким и лингвистичким асоцијацијама које иду уз место рођења. „Ове мреже/везе су одређене комуникацијским моделима или моделима размена извора информација, уз учешће у социо-културним и политичким активностима. Са друге стране, идентитети многих особа или група људи дефинишу се кроз социјалне светове, који обухватају више од једног места". ${ }^{20}$ Транснационална перспектива у контексту реп лирике са простора бивше југословенске музичке сцене везује се за посебна уређења и динамику конструкције, преговарања, репродукцију индивидуалних и групних идентитета.

\section{„Yugospotting” као симболична јужнословенска идентификачија}

Као концепт, југоспотинг се намеће сам по себи, захваљујући великом броју реп текстова у којима се изводе југо-референце. Префикс југо је можда рестриктиван, старомодан, колико и провокативан. Али он је, исто тако, једини који својим конотацијама усмерава мисли ка југословенском, социјалистичком хронотопу, некадашњој унији федеративних република. Даље, тај префикс је више него практичан при анализи заједништва кроз културне и музичке укусе формираних након распада СФРЈ. Сам концепт југоспотинга даје могућност да се сагледа шта се заправо десило са бившим међу-генерацијским ресурсима после распада заједничке државе. Југоспотинг се тако бави постјугословенским културним идентитетима и схватањем нужности одређеног културног заједништва које мора бити именовано. Југоспотинг има за циљ да истражи како су чланови прве прослављене генерације балканских репера успели у томе да приволе своју публику на особине реп сцене као регионалне или транснационалне, и да је подсете на културолошко и језичко наслеђе које је ,југословенство" уткало у сада регионални реп. Поред овога, југоспотинг открива конективну природу популарне музике у претходној држави, а онда и конективни карактер савременог репа у Региону. На концу, ако се локална култура увек надовезује на неку ранију културу тог

19 Vertovec, S. (2007) Super-diversity and its implications, Ethnic and Racial Studies, 30:6, pp. 573, 1024-1054.

20 Исто. 
места, онда се реп музика на просторима бивше Југославије не надовезује ни на једну другу него на ону - југословенску. Зато је, чини се, реперима лако да користе музичке и лиричке ресурсе из претходне државе. А делимично су и приморани на то.

Како се концепт југоспотинга уклапа теоретски и методолошки у широку академску дискусију о југо-носталгији ${ }^{21}$, југосфери (Yugosphere) ${ }^{22}$, постјугословенској култури ${ }^{23}$, заједничкој југословенској култури? ${ }^{24}$ Југоспотинг се не наставља директно на дискурс носталгије, ${ }^{25}$ већ произилази из саме праксе, културе, сензибилитета реп текстова и њихових стваралаца, оних који детектују, али који се не осврћу носталгично на југо-особине у репу и хип-хопу. Веза југоспотинга и носталгије види се у сентиментима и емоцијама, али и у прослави дуговечности „старих” културних искустава, која су преокренута у нова музичка и лиричка искуства, као што су то семплови и интертекстуалност у стиховима. Не можемо овде изоставити ни комерцијалност реп лирике, ни распрорострањеност реп публике, нити конструкције заједничких трансмодерних идентитета који нису у вези са националистичким осећањима, а који су транснационални по својој природи, позитивно постјугословенски и балкански и регионални. Југоспотинг се, заправо, највише може објаснити концептом културне интимности (cultural intimacy) Мајкла Херцфелда (Michael Herzfeld), или који може бити један његов регионални облик. ${ }^{26}$ Као антрополошко средство, овај концепт може допринети разговорима о национализму и другим облицима формирања идентитета,

21 Lindstrom, N. (2006) Yugonostalgia: Restorative and Reflective Nostalgia in Former Yugoslavia, East Central europe 32 (1-2), pp. 7-55; Velikonja, M. (2009) Lost in Transition: Nostalgia for Socialism in Post-Socialist Countries, East-European Politics and Societies 23 (4), pp. 535-551; Volčić, Z. (2007) Scenes from the Last Yugoslav generation: The Long March from Yugo-utopia to Nationalisms, Cultural Dynamics 19 (1), pp. 67-89.

22 Judah, T. (2009) Yugoslavia is Dead: Long Live the Yugosphere, LSEE Research on South Eastern Europe Working Paper, London.

23 Longinović, T. Z. Post-Yugoslav Emergence and the Creation of Difference, in: After Yugoslavia: The Cultural Spaces of a Vanished Land, ed. Gorup, R. (2013), Stanford: Stanford University Press.

24 Milutinović, Z. What Common Yugoslav Culture Was, and How Everybody benefited from it, in: After Yugoslavia: The Cultural Spaces of a Vanished Land, ed. Gorup, R. (2013), Stanford: Stanford University Press; Wachtel, A. (1998) Making a Nation, Breaking a Nation: Literature and Cultural Politics in Yugoslavia, Stanford: Stanford University Press.

25 Velikonja, M. New Yugoslavism in Contemporary Popular Music in Slovenia, in: Post-Yugoslavia. New Cultural and Political Perspectives, eds. Abazović, D. and Velikonja, M. (2014), Palgrave Macmillan, p. 62.

26 Hertzfeld, M. (2004) Cultural Intimacy: Social Poetics in the nation-state, London: Routledge, p. 3. 
који заправо манифестују у највећој могућој мери разумевања многоструке прошлости која се обично одиграва унутар интимне сфере културе. ${ }^{27}$ Културна интимност се противи формализму културног национализма, те може да сугерише добоки осећај културне и политичке рањивости. Због тога се културна интимност може сматрати рационалним и ефикасним средством за локализовање специфичних динамика културног срама и солидарности. Концепт југоспотинга, као облика културне интимности, помаже у анализи колективних и индивидуалних перформанси личног у реп лирици.

У данашњем политичком дискурсу, префикс ,jуго" лако се може сматрати негативним, чак непотребним. Међутим, у контексту популарне музике, тај префикс повезује и рефлектује историјски контекст културне револуције југословенске популарне музике средином 70-их, када је она постала (друштвено) посвећена, ${ }^{28}$ те на тај начин и први аутентично југословенски облик популарне културе. У то време, у популарној култури се, према Мишини, радило пре свега о садржаjу. ${ }^{29}$ Такозвани „нови талас” рок музике је настао у време „социјалистичког хуманизма”, који је био дериват Западног марксизма. Трансформација југословенске рок музике је у то време била под јаким утицајем етоса британског панка, у чијем центру се налазило веровање да би рок музика требало да буде облик социо-културне праксе са задатком да говори „истину онима који држе моћ у рукама” и да обезбеди популарно-културни простор за активни ангажман. Иако је панк музика наводно била против званичног друштва, југословенски рок тог времена је више био оријентисан ка социјалистичком југословенском друштву, тј. тежњама да се оно усаврши. Нови музички покрети, попут новог таласа, новог примитивизма и новог партизанства, ${ }^{30}$ позиционирали су се као друштвена критика националног културног апарата, са стратегијом да се југословенски комунизам и праксом што више приближи идеалу социјализма који би одговарао друштву „по мери људскости”. Хуманизам и заједништво су као теме наставиле да се провлаче и у реп лирици, која по свом карактеру већ садржи елементе социјалног ангажмана. У таквој реп лирици, лични наративи, који су до скора били схватани као болни и збуњујући, приказани су као део

27 Исто, стр. 12.

28 Mišina, D. (2013) (What's so funny 'bout) peace, love \& understanding': rock culture and the rebuilding of civic identity in the post-conflict Balkans, in: Identities: Global Studies in Culture and Power, Vol. 20, No. 3, pp. 304-325.

29 Ието.

30 Исто. 
стварности, на онај начин како су је први репери доживљавали, и као појединци и као генерација.

\section{Југоспотинг и лични наративи}

Као део хип-хоп културе, реп музика користи широку палету лингвистичких и идеолошких ресурса, као и понекад конфузну естетику. Али свим тим особинама она успева да „Ухвати тренутак” стварности. Како музички тако и вербално, реп се због првобитне, сада већ помало избледеле мантре keeping it real и оданости уличном духу, често види у облику платформе која има снажан друштвени кредибилитет. Због ратова вођених током 90-их година, савремена, самостална западно-балканска друштва започела су своје нове историје у знаку трауматичности и отупелости. У таквој атмосфери ce развијао и хип-хоп, као grass root феномен новијег времена, поставши важним индикатором стварних друштвених проблема у Региону. Одсуство комуникације и ћутање, који су посебно обележили политичке дискурсе, убедљиво су описани у реп лирици, која је вербализовала људске и друштвено-политичке потребе, и документовала свакодневицу, умногоме промењену након 1990-их.

У реп лирици лични наратив се користи као техника привлачења пажње публике. Ем-Си то чини користећи се алтерегом, исказујући ставове и доказујући вербално умеће. Управо због своје наизглед аутобиографске природе, хипхоп је цењен као жанр. ${ }^{31}$ Српски репер Марчело користи ову технику дочаравајући слику породице, конкретно слику голог преживљавања и очевог принудног бављења шверцом. Као и многе друге породице, и његова је била увучена у зону тзв. „сиве економије”, услед економског расула 90их. Јефтину робу из Бугарске, Румуније и Мађарске по пијацама би продавали људи који су током дана обављали уобичајене, легалне послове. Необичан тренутак, када ненормално стање једне породице постаје нормално, описано је у следећим редовима:

Деведесет трећа, ћале се враћа из шверца.

Ја и деца испред зграде, наивни, пуни наде.

Враћа се уморан и тмуран, било је срања на граници.

Шљака само да буде око породице,

31 Rose, T. (2008) The Hip-hop Wars. What we talk about when we talk about hip-hop - and why it matters, Basic Books, p. 136; D'Urso, A. (2013) Life stories and sociological imagination: Music, private lives, and public identity in France and Sweden, Cambridge Scholars Publishing. 
па се смеши по навици да не сконтам.

И нисам контао: блејао с клинцима из краја,

триповао да је Бугарска нека земља до јаја.

Добро је, кажем, добро је - тата се само враћа са службеног пута.

Тресе прашину с капута, док моје радознале очи пиље:

Еј ћале, шта си ми донео?

Он се тужно смеши, кесу дреши, две чоколадице.

Две чоколадице - јеботе, ја скроз хепи! ${ }^{32}$

Ови редови, односно „лајнови” личног Ем-Сијевог наратива описују поразне ефекте сложених социо-економских промена, који су се догодили преко ноћи. На прелазу из наизглед безбрижног југословенског социјализма људи су остали препуштени сами себи, сналажењу у опасним шверцерским конвојима према Бугарској. Са овом променом цело друштво се нашло у позицији деградације, и друштвене и општељудске. Марчелов опис тог стања убедљиво говори о учинцима транзиције у комунистичким и социјалистичким друштвима, са тим изузетком што је у југословенском случају она била пропраћена ратом. Тренутак из 1993. године, коју описује Марчело, симболизује тешке и депресивне деведесете, чиме његова лирика постаје пример реп-документације, која чува сећање на личне и генерацијске историје.

Још један Марчелов текст, који се може сврстати у тзв. power poetry, јесте и композиција Сузе (2003), која је резултат заједничког рада српског и бошњачког репера Еда Мајке (Edo Maаajka). У њој се по први пут говори о мржњи, рату, али и о сарадњи која је превазилазила подељеност и сукобљеност.

Сузе за рају у старом крају, целом свету, нек знају,

Нек знају да се овде пуцало и плакало из истог очаја!

Нек знају да ни дан данас не знамо ни разлога ни значаја!

Рокао сам микрофон у Тузли, примили су ме као брата.

Па свима је доста рата! Мржња није наша, већ нам је дата.

О тата, реци, зар данас треба да мрзим Хрвата или Муслимана?

Па све нас мучи иста рана из старих дана... ${ }^{33}$

32 Marčelo (2003) De Facto. Na De Facto, Bassivity Music.

33 Marčelo (2003) Suze. Na De Facto, Bassivity Music. 
У време објављивања (2003), ови редови звучали су аутентично, а по својој тематици били су сасвим ретка појава на сцени. Марчелов реп говори о његовом реповању у Тузли, у месту у коме је он примљен као брат. Његова реп документација говори о првим културним активистима и акцијама, о концертима и сусретима са публиком преко граница. Употреба ратне и послератне тематике за своју реп лирику, посматрање, релативизација, дељење искустава, допринело је појави других југосферичних тема у репу, нарочито оних које се баве културном дезоријентацијом и осећањима социјалне издаје, искуство познато многим младима на простору бивше Југославије. Оваква врста реп документације осликава уједно и велике напоре везане за помирење народа који су прошли кроз заједнички конфликт. ${ }^{34}$ Генерација репера рођених крајем 70-их и почетком 80-их, одрађује свој део посла на помирењу. ${ }^{35}$ Међутим, важно је показати како су наступајуће генерације, које немају личних искустава из времена рата и живота у некадашњој државној заједници, одреаговали на сећања својих родитеља. ${ }^{36}$ Изненађујућа различитост у ставовима ратне и поратне генерације интересантна је како реперима тако и научним радницима. ${ }^{37}$

Сентиментално личном наративу из песме Сузе сличан је и онај у песми Носталаична (2004), сплитског реп састава TBF. Песма почиње семплом evergreen песме Све uто знаи о мени Арсена Дедића (1938-2015), познатог хрватског и југословенског кантаутора. Носталгична садржи исцрпан наратив о генерацији на прелазу из југословенског у постјугословенски хронотоп. Музички контекст песме, заједно са лириком, испуњен је уобичајеном генерацијском носталгијом, жалом за детињством, сладоледом, мирнодопским временом, као некаквим стандардом живљења. Осећање носталгије за простором из прошлости је присутна, али се само место, или име државе, не спомињу. Ипак, тензија између садашњег и ондашњег хронотопа говори нам да је садашњи хронотоп хрватски, а ондашњи - југословенски. Носталгична је композиција посвећена лудилу рата, послушности људи, говори о ратним лидерима, разградњи

34 Gordy, E. (2013) Guilt, Responsibility, Denial. The Past at stake in Post-Milosevic Serbia, Philadephia: University of Pennsylvania Press.

35 Pauker, I. (2006) Reconciliation and Popular Culture: A Promising Development in Former Yugoslavia, Local-Global No. 2, pp. 72-81.

36 Cvetanović, D. (2015) Balkanin nuoret konfliktin jälkeen (Youth in the after-war Balkan), Idäntutkimus vol. 4, pp. 28-44; Cvetanović, D. (2016) Brothers after arms - Balkan rappers as public intellectuals, Baltic Worlds, vol. 3, pp. 26-36.

37 Cvetanović, D. (2014) Petturien tai patriootien räppi (Traitor or Patriot rap?), Idäntutkimus Vol. 1, pp. 3-15. 
заједништва, генерацијском социјалном колапсу и апсурдности мешаних бракова. Полазишну тачку представљају сањиви описи сећања на позитивне ствари старог хронотопа, чиме се успоставља утопијска слика прошлости. Један од интерсантних елемената су и позајмљени стихови, лирични семплови унутар текста репа, „у земљи сељака, на брдовитом Балкану". Позајмица је препознатљива - реч је о стиховима баладе под називом Крвава бајка, песникиње Десанке Максимовић, из 1941. године ${ }^{38}$ Ова потресна песма о стрељању крагујевачких гимназијалаца током Другог светског рата, била је познато штиво и школска обавеза за многе генерације југословенских пионира. Ђаци су је учили напамет, али неретко су је и пародирали. Међутим, у лирици TBF-a, ова песма, као уметнута интертекстуална референца, издвојена је из идеолошко-дидактичког контекста обавезног учења о анти-фашистичкој борби, постајући тако, у новом историјском контексту, актуелна за једну нову генерацију. Наједном се неразумевање давног крвопролића преметнуло у његово пуно разумевање, кроз лично искуство новог историјског тренутка. Референца на песму Десанке Максимовић и генерацијско сећање на учење те песме, говори заправо о повезаности сплитских репера са некадашњим југословенским хронотопом. Управо ту се види и романтизовани опис југословеског хронотопа, у ком се учење Крваве бајке доживљавало као учење штива које је страно и историјски далеко.

Интересантан је и видео-клип који је урађен за композицију Носталгична: клип представља групу како перформира композицију у оквиру телевизијског програма који је стилизован по угледу на југословенске ТВ програме из 70-их. Не само музиком и реп лириком, већ и визуелним средствима покрећу се сећања на неко давно, минуло мирно време; сви елементи композиције имају исто усмерење: од „напаћене земље" до снова из срећних дана, са срећним људима и њиховом децом, који уживају у „свјету правде, братсва и једнакости".

И ове старе мелодије буде меморије

Чисте носталгије, и не знан шта ми је

Стари с бафама, стара с огромнон трајнон

Сестра и ја били умазан слајон

Ал дитету све је сјајно

38 О генерацијском значају ове песме видети: Arsenijević,V. et al. (2005)

Leksikon YUMitologije, Beograd: Rende, str. 207. 


\section{ДРАГАНА ЦВЕТАНОВИЋ}

Знан и онда није све било бајно

Ал пари ми се пуно липше

И ове капи кише ка да шапћу „никад више”

Јер све пролази, остаје само у нама

У срцима, у уму и фотоалбуму

Прича свака слика, да не заборавим никад

Насмијана лица неких старих прика

Неких нема више, остале су сјене

Мора бит да је с њима неста и дио мене

Ал врате га кише и витар с југа

Нека стара писма, носталгија и туга. ${ }^{39}$

Стихови TBF-оваца добра су илустрација за теорију носталгије Светлане Боум (Svetlana Boym): ${ }^{40}$ носталгија је везана за емоције губитка и расељености, али и за романтичну повезаност са фантазијама. Према Бојмовој, носталгична љубав може да преживи једино у везама на даљину, путем синематске слике. Носталгија се примећује двојако: код куће и у иностранству, садашњости и у прошлости, у сањарењу и у свакодневном животу. Композиција TBF-а осликава чежњу за детињством у југословенском хронотопу, те тако илуструје и аргумент Бојмове да је носталгија чежња за другим местом, временом детињства, споријим ритмом снова. ${ }^{41}$ Она носи жељу да се историјско време промени у приватну или колективну митологију, да се промени и време, и место, одбијајући да се преда неповратности времена које мучи људско стање. ${ }^{42}$ У том смислу, Носталгична представља добар пример артикулације односа који се развија између индивидуалног наратива и хронотопског тренутка; или као што то Бојмова каже, између индивидуалне биографије и биографије групе или нације, личног и колективног. ${ }^{43}$

Некад се питам јел трибало све баш тако бит

Па мислим трибало је бит кад је проклет ови свит

Добри људи увик извуку дебљи крај

Зато се надам да постоји пакал и рај

39 TBF (2004) Nostalgična. Na Maxon Universal, Menart.

40 Boym, S. (2007) Nostalgia and Its Discontents, The Hedgehog Review, p. 7.

41 Ието, стр. 8.

42 Ието.

43 Исто. 


\section{ДРАГАНА ЦВЕТАНОВИЋ}

Неки виши суд, Божја Правда

Да пресуди и казни сваког оног гада

Жељног рата и жедног крви

Али ко је без гријеха нек баци камен први

Иронично, заиста, да цитирам Криста

Један од оних што је одгојен у обитељи атеиста

У мраку, у мијешаном браку.

У некој далекој земљи сад је само у зраку

(и баш ме тамо донила рода)

Је, да не мрзим и будем поштен, искрен и одан

А разлику између зла и добра

Нисан научио ни од фратра, ни од хоџе, ни попа. ${ }^{44}$

Стих „Некад се питан јел трибало све баш тако бит” повезује личну носталгију са историјским тренутком, који је помутио личну историју. У том контексту је интересантно поставити питање расељености, с обзиром да Бојмова сматра да се у носталгичности ради о особи која балансира између припадања локалном и уневерзалном. ${ }^{45}$ Из овог разлога би се требало увек упитати, ко говори у име носталгије. ${ }^{46}$ Када реп генерација исказује носталгију, та се носталгија односи на време југословенског хронотопа, али и на почетке хронотопа постјугословенског. Оваква врста носталгије се према Бојмовој типологији назива рефлексивном, односно, оном која истражује начине насељавања неколиких места истовремено и замишљањем различитих временских зона. У том смислу, Носталгична не говори ни окаквој реконструкцији прошлости, већ у основи потврђује постојање „многоструких међусобно зараћених историја и истовремених темпоралности", ${ }^{47}$

Кад су завладали они шта су пали с крушке

Божји људи су благословили пушке

Овце слали у смрт за свога бога јединога

За лудило свога идеолога

И кад завлада мржња, разум није лијек

44 TBF (2004) Nostalgična. Na Maxon Universal, Menart.

45 Boym, S. (2007), нав. дело, стр. 12.

46 Исто, стр. 17.

47 Исто. 


\section{ДРАГАНА ЦВЕТАНОВИЋ}

И лудило увик промијени тијек повијести

Испише нову, крваву страну

У земљи сељака, на брдовитом Балкану

Зато летим високо изнад напаћеног тла

Далеко изнад поимања добра и зла

Високо горе, ка сунцу, у небеса

(ди се гужвају поруке ес-ем-еса)

Из овог вримена излазим ван

И зарањан у неки давни, заборављени сан

У неки бољи дан, пун смија и вица

Ди су сритни људи и њихова дица.

И гледају у сутра озарена лица,

Пуни наде, у том свиту правде.

Једнакости, братства и слободе.

(у свит љубави ме мисли воде)

И још увик вирујем да ће на овој планети

Једног дана сви људи моћ живит сретни

Разум, љубав и знање изградит ће рај

И знај, неће бит ироније за крај. ${ }^{48}$

Хумористичним приступом репу, ТВF успева да истовремено прикаже и утопичну и дистопичну слику стварности: користећи поетска решења позната из претходног социјалистичког система, која се везују за победу светлости над тамом, прогресивности над злом итд (према сунцу, према победи итд), реп наратор напушта садашњи тренутак, предајући се сада већ заборављеном сну о неком другом, савршеном тренутку, када су и одрасли и деца могли више да се смеју. Упркос утиску да се две именице, које су се у СФРЈ везивале за везу неколико народа, братство и јединство, користе и на помало ироничан начин, ова иронија је,

48 TBF (2004) Nostalgična. Na Maxon Universal, Menart. 
чини се, реперима ипак ближа него дистопична и конфузна садашњост.

$$
\text { Југоспотинг и ,Седма република” }
$$

Анти-ратна популарна музика је у југословенској сфери била присутна већ почетком 90-их, али су постјугословенске теме, попут рата, пост-ратног национализма и кризе цивилног друштва почеле да се јављају као тематика реп текстова. Исто тако, сарадње међу реп извођачима почеле су да бивају учесталије. Бављење друштвено-политичким темама, реп публика може некада доживети и као превише интелектуалне за жанр репа. ${ }^{49}$ Ипак, теме које повезују (реп)генерацију и два хронотопа, југословенски и постјугословенски, и чија се семантика може сагледати кроз концепт југоспотинга, повезана је и са идејом „седме републике”, коју је музичар и писац Анте Перковић обрадио у својој истоименој књизи $(2011)^{50}$. За њега „седма република” представља посебан ниво заједништва који је постојао у бившој Југославији, музика је била посебна репуб̆лика, кроз коју су млади могли да се (музички) идентификују. Шта ли је могла бити судбина једног оваквог заједништва, које се базира на личним афинитетима према музици, осећају за (матерњи) језик и за локалност музичког израза? „Седма република” према Перковићу (2011) није била анационална, колико јој је та тематика била незанимљива и излишна. Она је била вођена естетиком, која је била и критериј за добијање „држављанства”. И управо жанр који је затварао југословенско поглавље, нови талас, могао би да се осмотри као везивно ткиво одрођених саставница потоње Југосфере, (Региона, Западног Балкана, итд).

Перковићеву идеју о бесмртности „седме републике” лако је схватити применом концепта југоспотинга, који има за циљ да дефинише однос политичког контекста овог простора са наглим развојем хип-хоп културе. Одакле се та култура храни, шта је чини локалном, локализованом, шта су њене поджанровске специфичности, коју улогу је афроамеричка култура из 70-их играла у тренутку распадања једне европске државе и њене културолошке сфере? Од свог настанка, реп је често обрађивао и тешке теме, попут хомофобије, ксенофобије, десничарске политике, итд. Зашто би, међутим, било погрешно очекивати да се овакви заноси не наставе и у локализованим облицима репа? Југоспотинг је, у том смислу, важан начин артикулације генерацијских осећања,

49 Cvetanović, D. (2016) Brothers after arms - Balkan rappers as public intellectuals, Baltic Worlds, Vol. 3, pp. 26-36.

50 Perković, A. (2011) Sedma republika: pop kultura u Yu raspadu, Zagreb: Novi Liber; Beograd: JP Službeni glasnik. 
везаних и за формирање локалног реп израза и за формирање стања духа после социјално-политичких промена.

Теме југоспотинга се не односе на могуће поновно повезивање постјугословенског простора по узору на некадашњи социјалистички модел. Овакве теме у репу предлажу да се хип-хоп култура надовеже на наслеђе некадашње прогресивне и ангажоване музике, чији је један од (идеолошких) циљева био да „поправи” друштво и учини га бољим и прикладнијим за живот. Репери својим текстовима оцењују и стање друштва у коме тренутно живе, тражећи разлоге и образложења за дешавања из прошлости. Они такође своју пажњу усмеравају и на долазеће генерације и на врсту музичког, реперског заједништва које постоји међу њима и на сазнање шта са таквим заједништвом треба радити. Понајвише се у југоспотингу ради о тренутку, и о потреби за вербализацијом тренутака који су садашњем претходили.

Још једна категорија у репу коју југоспотингом можемо спознати није семантичка, већ управо језичка. Текстови у којима се спомињу теме југоспотинга изреповани су на језику који је изнутра подвојен политички. Реп, на свој начин, брилијантно коментарише и тренутну језичку расправу, наиме питање да ли су језици-наследници српско-хрватског или хрватско-српског различити језици, различити дијалекти, или је то један полицентрични језик који сваки говорник може да назива по својој жељи. Управо чињеница да је реп транснационално распрострањен, због могућности слушаности репа преко граница, могућа је и размена и ширење реп лексикона у све варијатне или језике одељене реп сцене. Једно лексичко решење из реп песме Стани на пут (2015), из истоименог докментарца, поменутог на почетку овог текста, сврстава реп (хип-хоп) културу у ван-национални простор: пар смислено-хумористичких редова хрватског репера $B a b y$ Dooks-a, посматра повезаност три народа кроз семантички акроним. Мешајући имена народа једних са другима, он, вероватно несвесно, поред осталог, прави и језички аргумент: они који разумеју како су ови „акроними” направљени ће разумети и језик и суштину која ју је заметнула:

\section{Хрби и Срвати, Страшни Каслимани $[\ldots]^{51}$}

Алудирајући поново на Перковићеву књигу Седма република, можемо поставити питање како је та република звучала. Перковић предлаже да је та млада, урбана, генерацијска република вероватно звучала као нови талас гитарског попа или рока, те била глас генерације која је реалативно чврсто

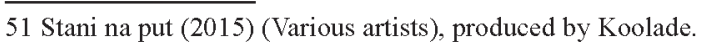


веровала у своје припадање једном простору. У складу са том логиком, репери, који користе многе музичке семплове „Седме републике”, покушавају да разлуче који је то њихов простор или простори којима музички и културолошки припадају. Алексеј Јурчак (Alexei Yurchak) је писао о инагурацијском тренутку када се генерацијски идентитет ствара. У случају ексјугословенских репера, тај тренутак је био везан за политички конфликт, те се може рећи да је реп баш из тог разлога постао генерацијски политичан и политички генерацијски од својих почетака. Композиција хрватског бенда Elemental Хеј Славени, из 2016, вербализује у виду химне и семпла бивше химне, постојање заједништва као неке врсте терета, а не пријатног сећања и потребе да се генерација „договори" са својом прошлошћу и крене напред, из неког новог почетка:

Опростите што носим сву ту пртљагу,

што ју распакиравам пред вама у Стразбуру и Хагу.

Што долазим с торбом пуном локалних срања

што зовем се Един, Ђорђе или Сања.

Допустите да будем грађанин свијета,

неоптерећен јармом балканског идентитета,

да стварам испочетка и да кројим свој пут,

да одговарам себи и само на себе будем љут.

И схватите да то што носим није моје,

да су други по мени шарали све те националне боје,

да сам одгајан да мрзим ал' се мржње сада срамим.

Да други су хтјели на истоку да се осамим

и схватите да ја јесам то што јесам

да моје знање и способност дефинирају што сам.

да је пун курац више то што носим ово бреме,

узмите си и носите све те ваше проблеме.

Хеј Славени, још сте живи, а давно требали сте нестати,

Хеј Славени, Ваше ватре још горе, не дају ми дисати.

На чијој си ти страни, чији, чији си ти, мали

Окрећеш ли капут који су ти дали 


\section{ДРАГАНА ЦВЕТАНОВИЋ}

Мијењаш ли боје попут камелеона

Гдје твој дистрикт, гдје је твоја зона

А ја би најрадије да нестанем

Срам ме, постидим се кад изрекнем

Одакле сам, тко сам, јер важу ми тежину

А најрађе бих све послала у материну.

Подвук'о бих црту и кренуо испочетка

У земљи гдје куће немају рупе од метка,

И кврагу ваши ратови и с вашег стола мрвице

И к врагу ваше Руже хрватске и Титове љубице

И кврагу ваше доктрине и велике нам вође,

а све ме то глође, до кости ме то глође.

Распижђен и луд, ово крик је у тами.

и јебем вам матер, снаћ ћемо се ми сами.

Човјек без народа, човјек без амблема.

Човјек без химне је човјек без проблема. ${ }^{52}$

\section{Дискусија}

Реп стваран на простору бивше Југославије, наставља да буде транснационално дељив локално, као врста домаћег културног производа. Југосферски ехо интересује репере регионалне сцене из разлога који су везани за генерацијску свест о настанку новог заједничког културолошког простора, који је од исте важности и за генерације које долазе. Реп лирика, која се води принципима културне интимности Југоспотинга, сугерише на постојање рационалних, свакодневних, универзалних идентитета, а не само „замишљених заједница". У овим текстовима отворена је дискусија припадања једној одређеној, тренутној локацији, која може бити национална, транснационална или глобална, и о својеврсном наставку идентификације са тренутком који је некада постојао, а који се сада сагледава кроз историјски наратив. Припадање месту, које је жанровска особина из које реп црпи своје теме, у случају текстова са југоспотинг контекстом

52 Elemental (2015) Hey Slavs. Na Tijelo, Uo Elemental. 
значи идентификацију са јужнословенским, југословенским и балканским културним простором. Репери 90-их и почетком су започели своје каријере као југословенски репери, а наставили као постјугословенски. Стога су многе теме везане за стварност која их окружује, за документацију тог окружења и дијагнозу проблема у коме се то окружење тренутно налази.

Сајмон Фирт (Simon Firth) тврди да је музика кључ идентитета, зато што подједнако интензивно нуди осећај и о себи и о другима, осећај за лично и за колективно. ${ }^{53}$ Он такође дефинише музику и идентитет као процесе у којима се ради о постојању а не о бивству, те о личном музичком искуству које се може назвати собом у процесу. ${ }^{54}$ И музика и идентитет су перформанси и наративи који описују и друштвено у индивидуалном и индивидуално у друштвеном. Према Фирту, у овим процесима је реч и о етици и о естетици. Везујући се за Марксову идеју да ако је музика метафора за идентитет, онда је личност увек замишљена личност која може бити замишљена као посебна организација друштвених, физичких и материјалних моћи. ${ }^{55}$

У свом социјално-политички ангажованом под-жанру реп музика је на простору бивше Југославије постала место на којем се покрећу теме, личне и утолико пре - тешке, и теме које се могу доживљавати као политички некоректне. Овакав облик форума у коме се отворено говори о прошлости зарад садашњих, а нарочито будућих генерација, на овим просторима је редак и зато културолошки важан. Овај чланак је кроз само неке примере покушао да приближи коцепт Југоспотинга и начине на који он покушава да дефинише припадање једној широј, инклузивној и ексклузивној заједници. Чак и упркос томе што се овај поджанр репа не сматра као истински одраз уличног сензибилитета, већ радије као жанр који је придикујући, интелектуалан, он представља важан атрибут аутентичности постјугословенског репа, јер својим текстовима заправо образлаже оно што је Бејкерова објаснила следећим редовима: „послератна историја језика и културе у бившој Југославији је већ једним делом показала да Јужни Словени нису припадали толико међусобно различитим културама, колико су њихове вође својевремено хтеле да поверују у то." ${ }^{56}$ Генерација репера, која је свој идентитет

\footnotetext{
53 Firth, S. Music and Identity, in: Questions on Cultural Identity, eds. Hall, S. and de Gay, P. (1996), Sage Publications, p. 110.

54 Исто, стр. 109.

55 Исто.

56 Baker, C. (2015) The Yugoslav Wars of the 1990s, London: Palgrave, p. 127.
} 


\section{ДРАГАНА ЦВЕТАНОВИЋ}

развила у једном специфичном културолошком тренутку, вероватно неће одустати од тога да у својим песмама искажу своју повезаност са окружењем у којем репују.

\section{ЛИТЕРАТУРА:}

Anderson, B. (1983) Imagined Communities: Reflections on the Origins and Spread of Nationalism, London: Verso.

Arsenijević,V. et al. (2005) Leksikon YU Mitologije, Beograd: Rende. Bhabha, H. (1994) The Location of Culture, London: Routledge.

Boym, S. (2007) Nostalgia and Its Discontents, The Hedgehog Review.

Cvetanović, D. (2014) Petturien tai patriootien räppi (Traitor or Patriot rap?), Idäntutkimus vol. 1, pp. 3-15.

Cvetanović, D. (2015) Balkanin nuoret konfliktin jälkeen (Youth in the after-war Balkan), Idäntutkimus, Vol. pp. 4, 28-44.

Cvetanović, D. (2016) Brothers after arms - Balkan rappers as public intellectuals, Baltic Worlds, Vol. 3, pp. 26-36.

Gordy, E. (2013) Guilt, Responsibility, Denial. The Past at stake in Post-Milosevic Serbia, Philadephia: University of Pennsylvania Press.

Hall, S., Held, D. and Mc Grew, T. (eds.) (1992) Modernity and Its Futures, Cambridge: Polity Press and Open University.

Hertzfeld, M. (2004) Cultural Intimacy: Social Poetics in the nation-state. London: Routledge.

Judah, T. (2009) Yugoslavia is Dead: Long Live the Yugosphere, LSEE Research on South Eastern Europe Working Paper, London.

Lindstrom, N. (2006) Yugonostalgia: Restorative and Reflective Nostalgia in Former Yugoslavia, East Central europe 32 (1-2), pp. 7-55.

Longinović, T. Z. Post-Yugoslav Emergence and the Creation of Difference, in: After Yugoslavia: The Cultural Spaces of a Vanished Land, ed. Gorup, R. (2013), Stanford: Stanford University Press, pp. 149-159.

Milutinović, Z. What Common Yugoslav Culture Was, and How Everybpdy benefited from it, in: After Yugoslavia: The Cultural Spaces of a Vanished Land, ed. Gorup, R. (2013), Stanford: Stanford University Press, pp. 75-87.

Mišina, D. (2013) (What's so funny 'bout) peace, love \& understanding: rock culture and the rebuilding of civic identity in the post-conflict Balkans, Identities: Global Studies in Culture and Power, Vol. 20, No. 3, pp. 304-325.

Pauker, I. (2006) Reconciliation and Popular Culture: A Promising Development in Former Yugoslavia, Local-Global, No. 2, pp. 72-81.

Perković, A. (2011) Sedma republika: pop kultura u Yu raspadu, Zagreb: Novi Liber; Beograd: JP Službeni glasnik. 


\section{ДРАГАНА ЦВЕТАНОВИЋ}

Rose, T. (2008) The Hip-hop Wars. What we talk about when we talk about hip-hop - and why it matters, Basic Books.

Todorova, M. (1997) Imagining the Balkans, Oxford: Oxford University Press.

D'Urso, A. (2013) Life stories and sociological imagination: Music, private lives, and public identity in France and Sweden, Cambridge Scholars Publishing.

Velikonja, M. (2009) Lost in Transition: Nostalgia for Socialism, in: Post-Socialist Countries, East-European Politics and Societies 23 (4), pp. 535-551.

Velikonja, M. New Yugoslavism in Contemporary Popular Music in Slovenia, in: Post-Yugoslavia. New Cultural and Political Perspectives, eds. Abazović, D. and Velikonja, M. (2014), Palgrave Macmillan.

Vertovec, S. (2007) Super-diversity and its implications, Ethnic and Racial Studies 30:6, pp. 573, 1024-1054.

Volčić, Z. (2007) Scenes from the Last Yugoslav generation: The Long March from Yugo-utopia to Nationalisms, Cultural Dynamics 19 (1), pp. 67-89.

Wallerstein, I. (1984) The Politics of the World-Economy: The States, the Movement and the Civilization, Cambridge: University of Cambridge Press Syndicate.

Wachtel, A. (1998) Making a Nation, Breaking a Nation: Literature and Cultural Politics in Yugoslavia, Stanford: Stanford University Press.

Wermuth, M. Rap in Low Countries, in: Global Noise: Rap and Hiphop outside the USA, ed. Mitchell, T. (2001), Middletown, CT: Wesleyan University Press.

\section{Дискографија:}

Elemental (2015) Hey Slavs. Na Tijelo, Uo Elemental.

Marčelo (2003) De Facto. Na De Facto, Bassivity Music.

Marčelo (2003) Suze. Na De Facto, Bassivity Music.

Stani na put (2015) (Various artists), produced by Koolade.

TBF (2004) Nostalgična, Na Maxon Universal, Menart. 


\title{
ДРАГАНА ЦВЕТАНОВИЋ
}

\section{Dragana Cvetanović}

\author{
Helsinki, Finland
}

\section{YUGOSPOTTING IN THE REGIONAL HIP-HOP}

\begin{abstract}
Through the concept of 'Yugospotting' this article explores how some established post-YU rappers, armed with the rap language and the strong generational knowledge, have constructed common identities in the new supranational social context before their shared rap audiences. What kind of transnational post-Yugoslav rap scene has been constructed by employing inherited ex-Yugo-knowledge and rappers 'hiphopographies'? Could this (mis)sampling of Yugoness and Balkanness be a significant identification base for the future rap generations of the "region"?
\end{abstract}

Key words: Yugoslavia, region, hip-hop, rap, identity, cultural policy, intertextuality

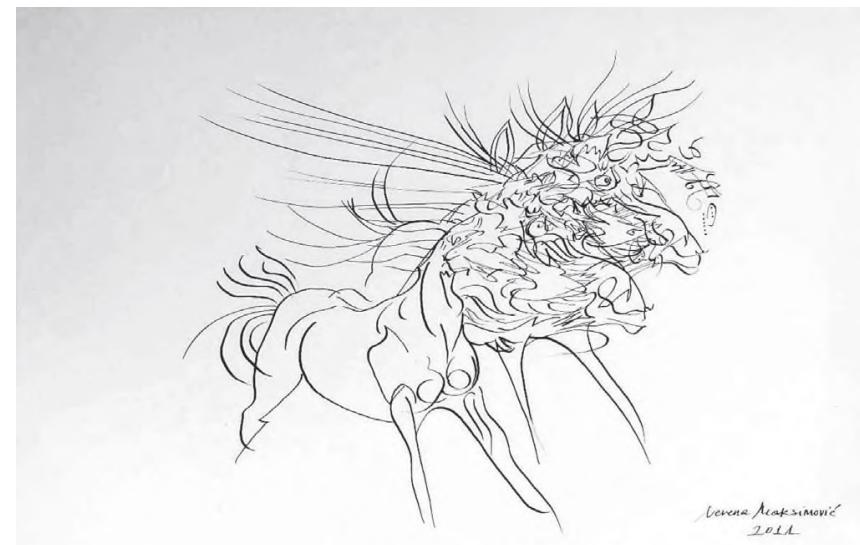

Невена Максимовић, Коњ $и$, цртеж, 2011. 